\title{
ANALISIS FAKTOR YANG MEMPENGARUHI KEJADIAN ANEMIA MAHASISWA DIII KEBIDANAN UNIVERSITAS MUHAMMADIYAH PURWOKERTO
}

\author{
Dewi Ambarwati ${ }^{1}$,Wilis Dwi Pangesti ${ }^{2}$ \\ ${ }^{1,2}$ Program Studi Kebidanan DIII Fakultas Ilmu Kesehatan, Universitas Muhammadiyah Purwokerto \\ Email: dwambarwt@gmail.com
}

\begin{abstract}
ABSTRAK
Masa remaja sering disebut dengan masa pubertas. Pubertas adalah perubahan cepat pada kematangan fisik yang meliputi perubahan tubuh dan hormonal, terutama terjadi selama masa remaja awal. Masalah gizi yang biasa dialami pada fase remaja adalah status gizi dan anemia. Tujuan penelitian ini untuk mengetahui faktor-faktor yang dapat mempengaruhi kejadian anemia pada remaja pada mahasiswa Prodi Kebidanan DIII FIKES UMP tahun 2017. Penelitian ini adalah penelitian analitik. Pendekatan waktu yang digunakan adalah cross sectional. Analisis data dalam penelitian dengan variabel berskala Nominal dan Nominal adalah statistika non-parametrik. Pengujian hipotesis mengunakan Uji Chi Square. Hasil penelitian menunjukkan tidak ada hubungan antara status gizi, uang jajan dan pendapatan orang tua yang signifikan dengan nilai $p$-Value > 0,05 secara berurutan nilai $\mathrm{X}^{2}$ hitung adalah $3,679,1,75$ dan 0,285 , dan Ada hubungan yang signifikan antara tingkat pengetahuan mahasiswa dan tingkat pendidikan terakhir ibu dari mahasiswa dengan nilai $p$ valeu $<0,05$ secara berurutan nilai $\mathrm{X}^{2}$ hitung 16,746 , dan 8, 014. Penelitian ini dapat disimpulkan bahwa tidak ada hubungan antara status gizi, uang jajan dan pendapatan orang tua terhadap angka kejadian anemia remaja dan Ada hubungan antara tingkat pengetahuan mahasiswa dan tingkat pendidikan terakhir ibu dari mahasiswa dengan kejadian anemia remaja.
\end{abstract}

Kata Kunci : Status Gizi; Uang Jajan; Pendapatan Orang Tua; Pengetahuan; Pendidikan terakhir Ibu; Anemia

\section{THE ANALYSIS OF AFFECTING FACTORS OF ANEMIA IN STUDENTS OF DIPLOMA MIDWIFERY PROGRAM OF STUDY AT HEALTH SCIENCE FACULTY UNIVERSITY OF MUHAMMADIYAH PURWOKERTO}

\begin{abstract}
Adolescence is often referred to as puberty. Puberty is a rapid change in physical maturity that includes bodily and hormonal changes, the emergence of adolescence. Common nutritional problems in the adolescent phase are nutritional status and anemia. The purpose of this study was to determine the factors that may affect the incidence of anemia in adolescents in the students of Diploma Midwifery Program of Study at Health Science Faculty University of Muhammadiyah Purwokerto in 2017. This research was an analytic research. The time approach used was cross sectional. Data analysis in research with variable of Nominal and Nominal scale is non parametric statistic. Hypothesis testing used Chi Square Test. The results showed no relationship between nutritional status, pocket money and significant parent with p-value> 0,05 in sequence value of X2 count was $3.679,1.75$ and 0.285 , and there was a significant relationship between the level of student knowledge and the level the last education of mothers of students with $p$ value $<0.05$ consecutive values X2 count 16,746 , and 8 , 014. This research can be concluded there is no correlation between nutritional status, pocket money and parent income to the incidence of adolescent anemia incidence and There is correlation between student's knowledge level and the last education level of mothers of students with the incidence of adolescent anemia.
\end{abstract}

Keywords: Nutritional Status, Pocket money, Parent Revenue, Knowledge, Mother's last education, Anemia.

Jurnal SMART Kebidanan Sekolah Tinggi Ilmu Kesehatan (STIKes) Karya Husada Semarang www.stikesyahoedsmg.ac.id/ojs/index.php/sjkb 


\section{Pendahuluan}

Masa remaja sering disebut dengan masa pubertas. Pubertas adalah perubahan cepat pada kematangan fisik yang meliputi perubahan tubuh dan hormonal, terutama terjadi selama masa remaja awal. Pada remaja putri yaitu terjadinya menarche (menstruasi) yang pertama. Adanya perkembangan untuk mencapai kematangan mental, emosional, sosial, dan fisik oleh remaja, maka banyak persoalan yang dihadapi pada remaja tersebut dan berkaitan dengan masalah gizi. Masalah-masalah gizi dan kesehatan yang dihadapi remaja saling berkaitan satu sama lain. Adapun masalah-masalah gizi yang biasa dialami pada fase remaja adalah status gizi dan anemia. Anemia masih menjadi masalah kesehatan utama di Indonesia. Beberapa penelitian menunjukkan bahwa anemia memiliki dampak yang tidak ringan dimana keadaan anemia dapat mengakibatkan penurunan konsentrasi belajar dan bahkan dapat mengakibatkan gangguan pada masalah obstetri seperti masa kehamilan, persalinan dan masa nifas dan menimbulkan permasalahan pada janin maupun bayi baru lahir seperti bayi lahir prematur, BBLR dll. (Pratiwi, 2016)

Anemia merupakan keadaan dimana terjadi penurunan jumlah eritrosit yang ditunjukkan oleh penurunan kadar haemoglobin, hematokrit dan hitung eritrosit. Anemia masih menjadi masalah kesehatan utama diindonesia selain masalah kekurangan energi protein, kekurangan vitamin A dan gangguan akibat kekurangan iodium (GAKI). Berdasarkan data Riskesdas 2013, prevalensi anemia di Indonesia yaitu 21,7\%, dengan proporsi $20,6 \%$ di perkotaan dan $22,8 \%$ di pedesaan serta $18,4 \%$ laki - laki dan 23,9\% perempuan. (Kemenkes, 2007)

Terdapat hubungan antara, pengetahuan, soial ekonomi, pendidikan orang tua, pendapatan orang tua dan status gizi dengan kejadian anemia. Penelitian lain juga menyebutkan bahwa dampak anemia pada masa remaja dapat menurunkan kemampuan dan konsentrasi belajar, mengganggu pertumbuhan sehingga tinggi badan tidak mencapai optimal, menurunkan kemampuan fisik olahragawati dan mengakibatkan muka pucat. (Pratiwi, 2016) (Martini, 2015)

Berdasarkan hasil wawancara dengan bagian seksi gizi Dinas Kesehatan Kabupaten Banyumas, Angka kejadian anemia remaja sebesr $86,5 \%$. Sejalan dengan hasil observasi yang dilakukan oleh peneliti terhadap mahasiswa kebuidanan DIII sering kali mahasiswa tidak melakukan sarapan pagi, pada saat mengikuti proses pembelajaran mahasiswa terlihat mengantuk dan bahkan beberapa kali terdapat mahasiswa yang mengalami penurunan 
kesadaran dan setelah dilakukan pemeriksaan mahasiswa mengalami anemia dan tekanan darah menurun. (Dinkes, 2016)

Berdasarkan hal tersebut penulis ingin mengetahui tentang "Faktor-faktor yang mempengaruhi kejadian anemia pada mahasiswa Prodi Kebidanan DIII Fakultas Ilmu kesehatan Universitas Muhammadiyah Purwokerto tahun 2017 ".

Tujuan Penelitian ini untuk mengetahui gambaran kejadian anemia, hubungan faktor status gizi terhadap kejadian anemia remaja, mendiskripsikan hubungan faktor pengetahuan tentang anemia remaja, mendiskripsikan hubungan faktor pendidikan ibu, uang jajan yang diberikan orang tua dan pendapatan orang tua dengan kejadian anemia pada mahasiswa Prodi DIII Kebidanan Fikes UMP.

\section{Tinjauan Teoritis}

\section{Anemia Zat gizi besi (Fe)}

Tanda-tanda dari anemia gizi dimulai dengan menipisnya simpanan zat besi (feritin) dan bertambahnya absorbsi zat besi yang digambarkan dengan meningkatnya kapasitas pengikatan zat besi. Pada tahap yang lebih lanjut berupa habisnya simpanan zat besi, berkurangnya kejenuhan transferin, berkurangnya jumlah protoporpirin yang diubah menjadi heme dan akan diikuti dengan menurunnya kadar feritin serum. Akhirnya terjadi anemia dengan cirinya yang khas yaitu rendahnya kadar Hemoglobin. (Pratiwi, 2016)

Tabel 1. Batas normal terendah nilai hemoglobin

\begin{tabular}{cc}
\hline Usia & Kadar Hb (g/dl) \\
\hline 1 & 2 \\
Anak usia 6 bulan-5 tahun & 11,0 \\
Anak usia 6-18 tahun & 12,0 \\
Wanita dewasa & $12,0-14,0$ \\
\hline
\end{tabular}

\section{Faktor yang mempengaruhi Anemia}

Secara umum, status anemia dipengaruhi oleh empat variabel utama yaitu infeksi, konsumsi pangan, keadaan fisiologi, dan pengeluaran zat besi oleh tubuh. Selain itu, terdapat faktor-faktor lain yang berpengaruh terhadap kejadian anemia antara lain pendidikan, jenis kelamin, wilayah, kebiasaan sarapan, status kesehatan, dan keadaan IMT (Indeks Massa 
Tubuh) dalam kategori kurus. Hasil penelitian lain menunjukkan bahwa faktor risiko yang secara signifikan mempengaruhi kecenderungan status anemia mahasiswa baru yaitu faktor jenis kelamin, umur, pendapatan orangtua, dan status proteinuria.

Keadaan Indeks Massa Tubuh (IMT) dalam kategori kurus mempunyai kecenderungan untuk terkena anemia. Menurut Thompson, pertumbuhan yang terganggu berhubungan dengan anemia defisiensi besi dan Indeks Massa Tubuh (IMT) secara positif berhubungan dengan konsentrasi hemoglobin seseorang. Namun hasil tersebut berbeda dengan kelompok wanita usia subur di Lebanon, yang menunjukkan bahwa tidak adanya hubungan IMT dengan status anemia.

Status gizi adalah keadaan seseorang yang diakibatkan oleh konsumsi, penyerapan, dan penggunaan zat gizi dari makanan dalam jangka waktu yang lama. Penilaian status gizi secara langsung dapat dibagi menjadi empat penilaian yaitu antropometri, klinis, biokimia, dan biofisik. Pengukuran antropometri terdiri dari dua dimensi yaitu pengukuran pertumbuhan dan komposisi tubuh (pengukuran komponen lemak dan komponen bukan lemak).

Indikator antropometri yang dipakai di lapangan adalah berat badan untuk mengetahui massa tubuh dan panjang atau tinggi badan untuk mengetahui dimensi berat linear dan indikator tersebut sangat tergantung pada umur. Berikut adalah rata-rata berat badan dan tinggi badan wanita berdasarkan usia menurut WNPG 2004. (Arumsari, 2008)

Tabel 2. Rata-rata BB dan TB wanita berdasarkaan Usia

\begin{tabular}{lcccc}
\hline Usia & $\begin{array}{c}\text { Rata-rata BB } \\
(\mathbf{K g})\end{array}$ & SD & Rata-rata TB $(\mathbf{C m})$ & SD \\
\hline 10-12 tahun & 38.4 & 9.2 & 145.4 & 8.8 \\
13-15 tahun & 44.6 & 6.7 & 152.3 & 4.6 \\
16-18 tahun & 46.3 & 4.6 & 149.1 & 4.9 \\
\hline
\end{tabular}

\section{Metode Penelitian}

Penelitian ini termasuk penelitian analitik. Desain penelitian kasus kontrol, kasus dan kontrol telah diketahui pada saat awal penelitian dengan melakukan pemeriksaan kadar haemoglobin secara digital, kemudian ditelusuri faktor-faktor yang berperan terjadinya anemia remaja. Dalam rancangan penelitian ini tidak dilakukan pencocokan (unmatching) pada kasus dan kontrol. 
Populasi dikelompokan menjadi dua: Populasi kasus adalah seluruh mahasiswa prodi kebidann DIII FIKES UMP tingkat 1 dan 2 yang berusia 15-19 tahun yang mengalami anemia. Populasi kontrol adalah seluruh mahasiswa prodi kebidann DIII FIKES UMP tingkat 1 dan 2 yang berusia 15-19 tahun yang mengalami anemia. Sampel pada penelitian ini digunakan system total sampling. Variabel independent terdiri dari: pendidikan terakhir ibu, uang jajan dan pendapatan orang tua.Variabel dependent adalah Anemia Remaja. Analisis data menggunakan menggunakan chi Square $\left(X^{2}\right)$ dengan tingkat kepercayaan 95\%. (Sugiyono, 2010)

\section{Hasil Penelitian}

Tabel 3. Distribusi Hubungan status gizi (IMT) dengan kejadian anemia

\begin{tabular}{|c|c|c|c|c|c|c|}
\hline & & \multicolumn{2}{|c|}{ Gizi } & \multirow[t]{2}{*}{ Total } & \multirow[t]{2}{*}{$X^{2}$} & \multirow[t]{2}{*}{ Pvalue } \\
\hline & & $\begin{array}{l}\text { Status Gizi } \\
\text { Kurang }\end{array}$ & $\begin{array}{l}\text { Status Gizi } \\
\text { Normal }\end{array}$ & & & \\
\hline \multirow[t]{2}{*}{ Anemia } & Anemia & 6 & 25 & 31 & 3.679 & 0.055 \\
\hline & tidak anemia & 1 & 28 & 29 & & \\
\hline Total & & 7 & 53 & 60 & & \\
\hline
\end{tabular}

Berdasarkan tabel 3 diatas, hubungan status gizi (IMT) dengan kejadian anemia menghasilkan nilai $\mathrm{X}^{2}=3.679$ dan $P$ Value 0.055 .

Tabel 4. Distribusi hubungan pengetahuan dengan kejadian anemia

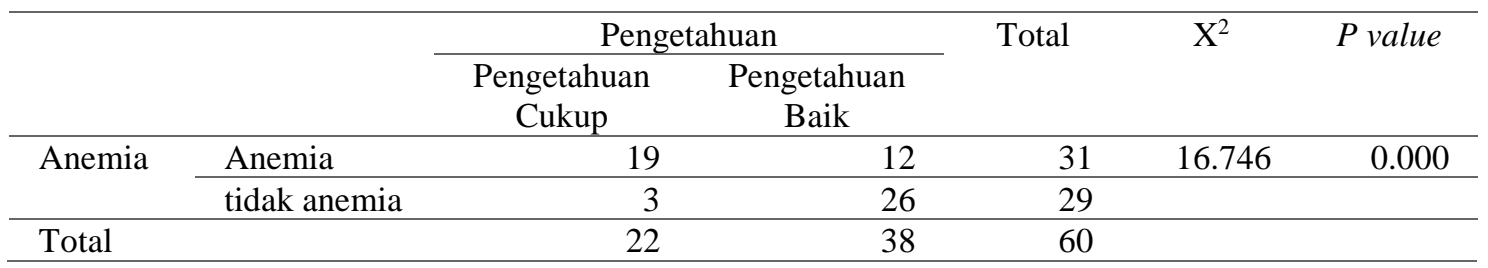

Berdasarkan tabel 3 diatas, hubungan pengetahuan dengan kejadian anemia menghasilkan nilai $\mathrm{X}^{2} 16.746$ dan $P$ Value 0.000 .

Tabel 5. Distribusi hubungan pendidikan terakhir ibu dengan kejadian anemia

\begin{tabular}{llrrrrrr}
\hline & & \multicolumn{2}{c}{ Pendidikan Ibu } & Total & $\mathrm{X}^{2}$ & P value \\
\cline { 3 - 7 } & \multicolumn{2}{c}{$\begin{array}{c}\text { Pendidikan } \\
\text { Dasar }\end{array}$} & $\begin{array}{c}\text { Pendidikan } \\
\text { Menengah }\end{array}$ & & & \\
\hline \multirow{2}{*}{ Anemia } & Anemia & 22 & 9 & 31 & 8.014 & 0.000 \\
\cline { 2 - 7 } & tidak anemia & 10 & 19 & 29 & & \\
\hline \multirow{2}{*}{ Total } & & 32 & 28 & 60 & & \\
\hline
\end{tabular}


Berdasarkan tabel 5 diatas, hubungan pendidikan terakhir ibu dengan kejadian anemia menghasilkan nilai $\mathrm{X}^{2} 8.014^{\mathrm{a}}$ dan $P$ Value 0.000 .

Tabel 6. Distribusi hubungan uang jajan dengan kejadian anemia

\begin{tabular}{llllllll}
\hline & & \multicolumn{2}{c}{ Uang } & Jajan & Total & $\mathrm{X}^{2}$ & P value \\
\cline { 3 - 7 } & & \multicolumn{2}{c}{$\begin{array}{c}\text { Kurang dari } \\
\text { median }\end{array}$} & $\begin{array}{c}\text { Lebih dari } \\
\text { median }\end{array}$ & & & \\
\hline \multirow{2}{*}{ Anemia } & Anemia & 4 & 27 & 31 & 1.75 & 0.185 \\
\cline { 2 - 7 } & tidak anemia & 1 & 28 & 29 & & \\
\hline Total & & 5 & 55 & 60 & & \\
\hline
\end{tabular}

Berdasarkan tabel 6 diatas, hubungan uang jajan dengan kejadian anemia menghasilkan nilai $\mathrm{X}^{2} 1.75$ dan $P$ Value 0.185 .

Tabel 7. Distribusi hubungan pendapatan orang tua dengan kejadian anemia

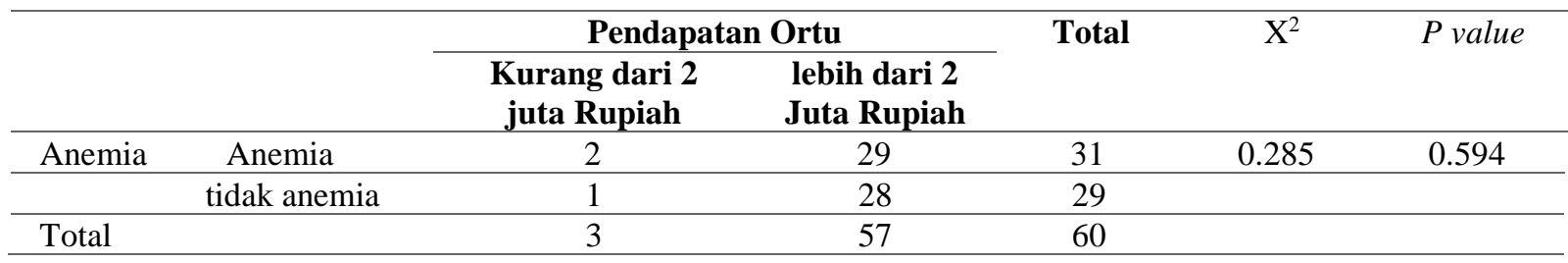

Berdasarkan tabel 7 diatas, hubungan pendapatan orang tua dengan kejadian anemia menghasilkan nilai $\mathrm{X}^{2} 0.285$ dan $P$ Value 0.594.

\section{Pembahasan}

\section{Hubungan status gizi (IMT) dengan kejadian anemia}

Berdasarkan analisis univariat menunjukan bahwa mahasiswa dengan status gizi normal lebih banyak dengan prosentase $88,7 \%$ dan hasil uji statistic dengan chi-square menunjukan probabilitas (p) lebih besar dari $\alpha(0,000>0,05)$. Hal ini menunjukan tidak adanya pengaruh status gizi mahasiswa terhadap kejadian anemia remaja.

Pengukuran paling reliabel untuk ras spesifik dan popular untuk menentukan status gizi pada masa remaja saat ini adalah Indeks Massa Tubuh (IMT). IMT merupakan indeks berat badan seseorang dalam hubungannya dengan tinggi badan, yang ditentukan dengan membagi BB dalam satuan kg dengan kuadrat TB dalam satuan meter. (Almatsier, 2003)

Masa remaja merupakan masa dimana seseorang mengalami berbagai perubahan secara pengetahuan, emosional, lingkungan social dan gaya hidup, hal ini dapat memiliki dampak yang sangat besar dalam kebiasaan makan remaja. 


\section{Hubungan pengetahuan mahasiswa dengan kejadian anemia}

Berdasarkan analisis univariat menunjukan bahwa mahasiswa dengan tingkat pengetahuan baik lebih banyak dengan prosentase $63,3 \%$ dan hasil uji statistic dengan chisquare menunjukan probabilitas (p) lebih besar dari $\alpha(0,000<0,05)$. Hal ini menunjukan adanya pengaruh tingkat pengetahuan mahasiswa terhadap kejadian anemia remaja.

Terdapat banyak faktor yang akan menyebabkan stimulus masuk dalam rentang perhatian seseorang. Faktor tersebut dibagi menjadi dua bagian besar yaitu faktor eksternal dan faktor internal. Faktor eksternal adalah faktor yang melekat pada objeknya, sedangkan faktor internal adalah faktor yang terdapat pada orang yang mempersepsikan stimulus tersebut. (Notoatmojo, 2010)

\section{Hubungan pendidikan terakhir ibu mahasiswa dengan kejadian anemia}

Berdasarkan analisis univariat menunjukan bahwa mahasiswa dengan tingkat pendidikan terakhir ibu dari mahasiswa dengan tingkat pendidikan dasar lebih banyak dengan prosentase 53,3\% dan hasil uji statistic dengan chi-square menunjukan probabilitas (p) lebih besar dari $\alpha(0,000<0,05)$. Hal ini menunjukan adanya pengaruh tingkat pendidikan terakhir dari ibu mahasiswa terhadap kejadian anemia remaja.

Faktor pendidikan dapat mempengaruhi status anemia seseorang berhunganuan dengan pemilihan makanan yang dikonsumsi. Tingkat pengetahuan yang lebih tingi akan mempengaruhi pengetahuan tentang gizi menjadi lebih baik dibadingkan dengan seseorang dengan pendidikan lebih rendah. (Permaesih, Herman S, 2005)

Tingkat pendidikan seorang ibu dapat berpengaruh terhadap pengetahuan, sikap dan ketrampilan dalam menentukan makanan keluarga. Peranan ibu sangat berpengaruh terhadap pembentukan pola kebiasaan makan remaja. Semakin tinggi tingkat pendidikan formal diharapkan semakin tinggi tingkat kesehatan seseorang, karena tingkat pendidikan kesehatan merupakan bentuk intervensi terutama terhadap perilaku kesehatan. Terdapat hubungan yang bermakna antara tingkat pendidikan ibu dengan anemia remaja. Berdasarkan hasil uji diketahui bahwa seorang remaja dengan pendidikan ibu rendah memiliki peluang untuk 1,945 kali untuk menderita anemia dibandingan dengan yang memiliki pendidikan ibu yang tinggi. (Yamin, Tenri, 2012)

\section{Hubungan uang jajan mahasiswa dengan kejadian anemia}

Berdasarkan analisis univariat menunjukan bahwa mahasiswa dengan uang jajan > median lebih banyak dengan prosentase $91,7 \%$ dan hasil uji statistic dengan chi-square 
menunjukan probabilitas (p) lebih besar dari $\alpha(0,000>0,05)$. Hal ini menunjukan tidak adanya pengaruh uang jajan mahasiswa terhadap kejadian anemia remaja.

Uang saku merupakan uang yang diberikan oleh orang tua dengan perencanaan dengan penggunaan uang tersebut. Penting untuk mengetahui jumlah uang saku anak untuk membeli makananan yang layak untuk dikonsumsi. (Elly, 2009)

\section{Hubungan pendapatan orang tua mahasiswa dengan kejadian anemia}

Berdasarkan analisis univariat menunjukan bahwa mahasiswa dengan status gizi normal lebih banyak dengan prosentase $95 \%$ dan hasil uji statistic dengan chi-square menunjukan probabilitas (p) lebih besar dari $\alpha(0,000>0,05)$. Hal ini menunjukan tidak adanya pengaruh pendapatan orang tua mahasiswa terhadap kejadian anemia remaja.

Pola konsumsi pangan secara makro berhubungan dengan hukum ekonomi, semakin meningkat pendapatan keluarga maka semakin beraneka ragam pola konsumsinya. Jika dalam keluarga mampu memberikan ragam pola konsumsi makanan yang ada, sehingga membuat seseorang terhindar dari kejadian anemia pada remaja. (Soekirman, 2000).

\section{Kesimpulan}

Ada hubungan yang signifikan antara tingkat pengetahuan mahasiswa dan tingkat pendidikan terakhir ibu dari mahasiswa dengan kejadian anemia. Tidak ada hubungan antara status gizi, uang jajan dan pendapatan orang tua dengan kejadian anemia.

\section{Saran}

Diharapkan remaja dapat lebih memperhatikan pola pemenuhan nutrisi dengan memanfaatkan uang saku yang mencukupi bagi pelaksanaan konsultasi kesehatan remaja . Diharapkan peran dari tenaga kesehatan lebih aktif lagi misalnya aktif dalam penyuluhan, meningkatkan dan merencanakan program kesehatan yang mampu memberikan informasi lebih lengkap tentang gizi dan kebutuhan nutrisi bagi tubuh remaja.

\section{Daftar Pustaka}

Almatsier. (2003). Prinsip dasar ilmu gizi. Jakarta: Gramedia.

Arumsari, E. (2008). Faktor risiko anemia pada remaja putri peserta program pencegahan dan penanggulangan anemia gizi besi (PPAGB) di kota Bekasi. Dipetik September 2016, dari http://academia.edu.documens 
Dinkes, S. (2016, Februari). Angka kejadian anemia remaja di kabupaten Banyumas. (D. Ambarwati, Pewawancara)

Elly. (2009). Perlukah anak diberi uang saku? Dipetik 20 Juni 2016, dari Detik.com: http://health.detik.com/read/2009/2009/09/02/164113/1195017/764/perlukah-anakdiberi-uang-saku

Gunatmaningsih, D. (2007). Faktor-faktor yang berhubungan dengan kejadian anemia pada remaja putri di SMA Negri 1 Kecamatan Jatibarang Kabupaten Brebes. Dipetik September 2016, dari http//digilib.unnes.ac.id

Kemenkes, B. P. (2007). Riset kesehatan dasar. Jakarta: Kemenkes.

Martini. (2015). Faktor-faktor yang berhubungan dengan kejadian anemia pada remaja putri di MAN 1 Metro. Jurnal kesehatan metro Sai Wai, Vol III No.1, Edisi Juni 2015. ISSN: $19779-469 X$.

Notoatmojo, S. (2010). Pendidikan dan perilaku kesehatan. Jakarta: Rineka Cipta.

Permaesih, Herman S. (2005). Faktor-faktor yang mempengaruhi anemia remaja. Bul. Penel. Kesehatan, Vol. 33, No.4, 162-171.

Pratiwi, E. (2016). Faktor-faktor yang mempengaruhi anemia remaja pada siswi MTS Ciwadan Cilegon Banten. Dipetik September 2016, dari http://repository.uinjkt.ac.id

Soekirman. (2000). Gizi dan aplikasinya untuk keluarga dan masyarakat. Jakarta: Depdiknas.

Sugiyono. (2010). Metodologi penelitian kuantitatif kualitatif dan RND. Bandung: Alfabeta.

Yamin, Tenri. (2012). Hubungan pengetahuan, asupan gizi, dan faktor lain yang berhubungan dengan kejadian anemia pada remaja putri di SMA kabupaten kepulauan Selanyar. Dipetik 20 Juni 2016, dari http://lib.ui.ac.id/file=digital/20318026-S-Tenri\%20Yamin.pdf 